\title{
KOMPARASI ESTIMASI RELIABILITAS PADA MATA PELAJARAN SEJARAH DITINJAU DARI HOMOGENITAS DAN HETEROGENITAS KELOMPOK
}

\author{
Eva Dina Chairunisa, Prodi Penelitian \& Pengukuran Pendidikan, SPs, UPI
}

\begin{abstract}
ABSTRAK
Tujuan penelitian ini adalah untuk memverifikasi adanya pengaruh homogenitas dan heterogenitas yang terdapat dalam kelompok terhadap nilai koefisien reliabilitas yang dihasilkan dengan menggunakan metode penelitian hubungan kausal. Penelitian ini dilakukan terhadap 400 siswa SMA di Kota Palembang yang terdiri dari 200 responden kelompok homogen dan 200 responden dari kelompok heterogen. Pengujian perbedaan dilakukan dengan menggunakan uji-U Mann Withney. Pengambilan sampel sebanyak 133 skor responden dilakukan dengan menggunakan teknik pengambilan sampel dengan pengembalian untuk dihitung koefisien reliabilitasnya, pengambilan sampel dilakukan sebanyak 30 kali, sehingga diperoleh masing-masing 30 buah koefisien reliabilitas untuk kelompok homogen dan kelompok heterogen. Hasil penelitian ini menunjukkan bahwa terdapat perbedaan yang signifikan pada koefisien reliabilitas yang dihasilkan kelompok homogen dan kelompok heterogen. Kelompok heterogen menghasilkan koefisien reliabilitas yang lebih tinggi dibandingkan dengan kelompok homogen yang menghasilkan koefisien reliabilitas lebih rendah. Temuan ini mendukung teori bahwa homogenitas dan heterogenitas mempengaruhi besaran nilai koefisien reliabilitas.
\end{abstract}

Kata kunci: Koefisien Reliabilitas, Homogenitas Kelompok, Heterogenitas Kelompok.

\section{PENDAHULUAN}

Dunia pendidikan terdapat kebutuhan pengukuran yang memadai terutama pada proses belajar mengajar. Proses pengukuran dimaksudkan untuk menghasilkan informasi akurat tentang perkembangan proses belajar, masalah yang terjadi dalam proses pembelajaran, dan untuk mengetahui apakah tujuantujuan dalam pembelajaran dan pendidikan telah tercapai.

Sejarah merupakan salah satu mata pelajaran di Sekolah Menengah Atas (SMA) mempelajari tentang peristiwa-peristiwa yang terjadi pada masa lampau baik, peristiwa nasional yang terjadi di Indonesia dan juga peristiwa yang terjadi di dunia internasional. Pembelajaran sejarah memiliki potensi besar untuk menanamkan nilai-nilai kebangsaan terhadap siswa. Hasan (2012:120) mengemukakan makna dari pendidikan sejarah,

“... pendidikan sejarah dimaknai sebagai upaya untuk mentransfer kemegahan bangsa masa lampau kepada generasi muda. Dengan posisi yang demikian maka pendidikan sejarah ditujukan untuk membangun kebanggaan bangsa dan pelestarian keunggulan tersebut."

Secara keilmuan, pembelajaran sejarah bertujuan untuk melatih kemampuan berpikir kronologis dan analitis, sehingga siswa mampu untuk menafsirkan sebuah peristiwa sejarah dan mengambil keputusan. Tentu kemampuan ini berguna bagi siswa dalam kehidupannya mendatang, karena siswa telah belajar untuk mengorganisasai peristiwa, menganalisisnya dan mengambil keputusan bagi prinsip dan kehidupannya.

Salah satu kegiatan dalam proses pembelajaran sejarah adalah adanya kegiatan penilaian untuk mengukur sejauh mana tujuan pembelajaran telah tercapai, untuk itu maka dilakukan tes. Tes didefinisikan sebagai suatu yang direncanakan untuk memperoleh informasi tentang trait atau atribut pendidikan atau 
psikologis yang setiap butir pertanyaan atau tugas tersebut mempunyai jawaban atau ketentuan yang dianggap benar (Zainul, 1993:

2). Tes hasil belajar adalah salah satu alat yang berfungsi untuk melakukan pengukuran pendidikan yang paling sering digunakan. Untuk itu dibutuhkan tes hasil belajar yang berkualitas, yaitu tes yang mampu menghasilkan informasi yang konsisten, stabil, dan terpercaya atau reliabel serta mampu menjalankan fungsinya dengan baik atau valid. Untuk menghasilkan tes hasil belajar yang valid, maka tes tersebut harus mampu menghasilkan data yang reliabel terlebih dahulu. Karena itu, para pembuat dan pengguna tes berusaha untuk mengkonstruksi tes yang memiliki nilai reliabilitas yang tinggi.

Dalam rangka menghasilkan reliabilitas yang tinggi pengembang tes melakukan beberapa cara untuk memaksimalkan nilai reliabilitas suatu tes hasil belajar tetapi beberapa cara tertentu memiliki kendala tersendiri, misalnya menambah jumlah butir soal atau mengkonstruksi perangkat tes yang memiliki aitem yang homogen dinilai kurang efektif, hal ini berkaitan dengan keterbatasan subjek baik penyusun tes maupun responden yang diberikan tes serta terbatasnya waktu yang tersedia untuk mengerjakan tes, sehingga perlu dipilih cara yang lebih efektif dan efisien untuk memaksimalkan nilai reliabilitas yang dihasilkan dalam pengkonstruksian tes dengan kualitas yang memadai dan mampu menjalankan fungsi tes.

Para ahli menyebutkan beberapa faktor yang mempengaruhi reliabilitas tes, diantaranya homogenitas kelompok responden. Pemilihan kelompok responden yang memiliki karakteristik heterogen, dapat dipilih menjadi salah satu upaya untuk meningkatkan relibilitas suatu tes. konsep reliabilitas dalam ujian tes klasik dapat diinterpretasi melalui enam cara diantaranya yang berkenaan dengan varian skor yang dihasilkan oleh kelompok responden yang dikenai tes, tinggi rendahnya koefisien reliabilitas akan tergantung pada besar kecilnya varian skor tampak pada populasi yang bersangkutan (Allen dan Yen, 1979, dalam Azwar, 2012: 32).

Karena itu, penelitian ini bertujuan untuk menyelidiki hubungan sebab akibat yang ditimbulkan oleh homogenitas dan heterogenitas dalam kelompok yang dikenai tes. Verifikasi dilakukan dengan cara membandingkan kelompok homogen dan kelompok heterogen yang dikenai tes yang sama, setelah dilakukan perhitungan varian skor untuk masing-masing kelompok, kemudian dilakukan perhitungan reliabilitas pada sampel skor.

Sehingga masalah yang dapat diidentifikasi dalam penelitian ini adalah mengenai perbedaan pada reliabilitas tes yang dihasilkan kelompok homogen dan kelompok heterogen, dan perbedan nilai daya beda sebuah butir soal dari masing-masing kelompok.

\section{METODE PENELITIAN}

Penelitian ini merupakan penelitian deskriptif, bertujuan untuk memverifikasi adanya perbedaan yang ditimbulkan oleh heterogenitas dan homogenitas dalam kelompok terhadap koefisien reliabilitas yang dihasilkan melalui tes hasil belajar sejarah. Tes hasil belajar sejarah dengan materi "Masa Pendudukan Jepang di Indonesia" diberikan pada siswa kelas XI IPS sebagai responden yang terbagi kedalam dua kategori, yaitu, kelompok dengan kategori heterogen dan kelompok dengan kategori homogen. Metode yang digunakan dalam penelitian ini adalah metode penelitian hubungan kausal atau causal comparative. Pada penelitian hubungan kausal, peneliti tidak melakukan intervensi atau melakukan perlakuan terhadap variabel 
bebas seperti halnya penelitian eksperimen, karena variabel bebas atau variabel sebab telah terjadi secara alami, tanpa campur tangan peneliti secara langsung.

Penelitian ini menggunakan desain penelitian a criterion group design (Fraenkel dkk, 2012: 370) yang membandingkan dua kelompok responden yaitu kelompok responden yang memiliki varian skor homogen (kelompok homogen) dan kelompok responden yang memiliki varian skor heterogen (kelompok heterogen).

Berdasarkan desain penelitian, terdapat dua kelompok responden yang akan dibandingkan, yaitu responden kelompok homogen merupakan siswa kelas XI IPS dari SMA Unggulan yaitu SMA Negeri 1 Palembang, SMA Negeri 5 Palembang, dan SMA Negeri 6 Palembang sebanyak 200 orang. Sedangkan responden kelompok heterogen adalah siswa kelas XI IPS dari SMA Reguler yaitu SMA Negeri 10 Palembang dan SMA Negeri 15 Palembang sebanyak 200 orang.

Populasi penelitian adalah skor tes hasil belajar sejarah yang dikenai pada kedua kelompok responden, sehingga diperoleh skor tes hasil belajar sejarah sebanyak 400 buah, yang terdiri dari 200 skor yang diperoleh dari kelompok homogen dan 200 skor yang diperoleh dari kelompok heterogen.

Sampel penelitian adalah skor yang diambil dari populasi skor tes hasil belajar sejarah yang dikenai pada responden. Sampel penelitian diambil dengan dengan menggunakan teknik penarikan sampel dengan pengembalian atau sampling with replacement. Sampling with replacement adalah cara pengambilan sampel dengan jumlah tertentu dan dikembalikan lagi ke populasi semula untuk mendapatkan peluang yang sama (Busnawir, 2006:26). Pengambilan sampel dengan metode ini kemungkinan setiap anggota populasi dipilih menjadi anggota sampel adalah $1 / \mathrm{N}$, tanpa memperhatikan berapa kali suatu subjek dalam populasi terpilih menjadi anggota sampel, sehingga ketelitian yang dimiliki sampel menjadi lebih tinggi untuk mengestimasi parameter dibandingkan teknik pengambilan sampel tanpa pengembalian.

Berdasarkan Slovin untuk menentukan ukuran sampel, maka jumlah sampel yang akan diambil adalah sebayak 133 sampel dari masing-masing kelompok homogen dan heterogen. kemudian sampel skor yang telah diambil dikembalikan lagi ke dalam populasi skor. Pengambilan masing-masing sampel akan diambil sebanyak 30 kali sehingga diperoleh data sebanyak $30 \quad(n=30)$ hal ini didasarkan kepada pendpaat Roscoe (1975) dalam Hendry (2012) yang menyatakan bahwa ukuran sampel yang dipecah menjadi subkelompok minimal adalah 30. Skor sampel dari 30 kali penarikan sampel ini kemudian dihitung koefisien reliabilitasnya. Sehingga diperoleh distribusi data koefisien reliabilitas sebanyak 60 buah koefisien reliabilitas. Masing-masing 30 data koefisien reliabilitas yang berasal dari kelompok homogen dan 30 data koefisien reliabilitas yang berasal dari kelompok heterogen.

Variabel bebas penelitian ini adalah variansi skor yang dihasilkan oleh kedua kelompok responden penelitian yaitu kelompok homogen dengan kelompok heterogen Sedangkan variabel terikat pada penelitian ini adalah koefisien reliabilitas tes hasil belajar sejarah yang diberikan pada kedua kelompok yang dibandingkan

\section{HASIL DAN PEMBAHASAN}

Hasil temuan pada penelitian ini dapat dilihat pada tabel 1 dan 2 . 
Tabel 1. Rekapitulasi Data Kelompok Homogen

\begin{tabular}{ccccccccc}
\hline \multirow{2}{*}{$\begin{array}{c}\text { Jumlah } \\
\text { Responden }\end{array}$} & $\begin{array}{c}\text { Jumlah } \\
\text { Aitem }\end{array}$ & Rerata & $\begin{array}{c}\text { Standar } \\
\text { Deviasi }\end{array}$ & Modus & Median & $\begin{array}{c}\text { Standar } \\
\text { Error }\end{array}$ & \multicolumn{2}{c}{ Skor } \\
\cline { 7 - 10 } & & Min & Max \\
\hline 200 & 35 & 21.52 & 3.762 & 19 & 21 & 0.265 & 8 & 30 \\
\hline
\end{tabular}

Tabel 2. Rekapitulasi Data Kelompok Heterogen

\begin{tabular}{cccccccc}
\hline \multirow{2}{*}{$\begin{array}{c}\text { Jumlah } \\
\text { Responden }\end{array}$} & $\begin{array}{c}\text { Jumlah } \\
\text { Aitem }\end{array}$ & Rerata & $\begin{array}{c}\text { Standar } \\
\text { Deviasi }\end{array}$ & Modus & Median & \multicolumn{2}{c}{ Skor } \\
\hline 200 & 35 & 17.51 & 5.369 & 19 & 17 & Min & Max \\
\hline
\end{tabular}

Berdasarkan tabel 1 dan 2 dapat dilihat sebaran data dari kedua kelompok yang dibandingkan. Data pada kelompok homogen memiliki sebaran data sempit dibandingkan dengan data kelompok heterogen yang memiliki sebaran data lebih lebar. Pengambilan data sampel skor dilakukan sebanyak 30 kali untuk masing-masing kelompok homogen dan kelompok heterogen, kemudian dihitung koefisien reliabilitasnya, sebaran data dari kedua kelompok dapat dilihat pada tabel 3 .

Tabel 3. Rekapitulasi Distribusi Data Koefisien Reliabilitas Kelompok Homogen dan Kelompok Heterogen

\begin{tabular}{lcc}
\hline \multirow{2}{*}{ Keterangan } & \multicolumn{2}{c}{ Kelompok } \\
\cline { 2 - 3 } & Homogen & Heterogen \\
\hline Rerata & 0.56 & 0.79 \\
\hline Standar Deviasi & 0.073 & 0.038 \\
\hline Nilai Minimum & 0.28 & 0.67 \\
\hline Nilai Maksimum & 0.67 & 0.84 \\
\hline Modus & 0.55 & 0.81 \\
\hline Median & 0.56 & 0.80 \\
\hline
\end{tabular}

Tabel 3 dapat dilihat kecenderungan nilai koefisien reliabilitas yang dihasilkan oleh kedua kelompok. Nilai koefisien reliabilitas kelompok homogen lebih kecil dibandingkan dengan kelompok heterogen, hal ini dapat dilihat melalui besaran nilai yang telah disajikan pada tabel 4.5. yaitu nilai rerata yang dihasilkan oleh kelompok homogen adalah 0.56 sedangkan nilai rerata yang dihasilkan oleh kelompok heterogen adalah 0.79 .

Pengujian persyaratan analisis berupa uji normalitas data dan uji homogenitas varians data, pengujian ini dilakukan terhadap data koefisien reliabilitas dari kedua kelompok sampel yang telah diperoleh sebelumnya untuk menentukan model pengujian signifikasi statistik perbedaan diatara kedua kelompok, berda-sarkan hasil pengujian dengan bantuan program SPSS 18.00 diperoleh data seperti pada tabel 4 dan 5 .

Tabel 4. Hasil Uji Normalitas (Kormogolov-Smirnov) Koefisien Reliabilitas Kelompok Homogen dan Kelompok Heterogen

\begin{tabular}{ccccc}
\hline Reliabilitas & $\mathrm{N}$ & $\begin{array}{c}\text { Taraf } \\
\text { Signifikansi }\end{array}$ & P-Value & Kesimpulan Data \\
\hline $\begin{array}{l}\text { Kelompok } \\
\text { Homogen }\end{array}$ & 30 & 0.05 & 0.001 & $\begin{array}{c}\text { Data Tidak } \\
\text { Terdistribusi Normal }\end{array}$ \\
\hline $\begin{array}{l}\text { Kelompok } \\
\text { Heterogen }\end{array}$ & 30 & 0.05 & 0.002 & $\begin{array}{c}\text { Data Tidak } \\
\text { Terdistribusi Normal }\end{array}$ \\
\hline
\end{tabular}

Tabel 5. Hasil Uji Homogenitas Varians Koefisien Reliabilitas Kelompok Homogen dan Kelompok Heterogen

\begin{tabular}{cccccc}
\hline Reliabilitas & $\mathrm{N}$ & $\begin{array}{c}\text { Taraf } \\
\text { Signifikansi }\end{array}$ & $\begin{array}{c}\text { Levene } \\
\text { Statistik }\end{array}$ & $\begin{array}{c}P \text { Value } \\
\text { Value }\end{array}$ & $\begin{array}{c}\text { Kesimpulan } \\
\text { Data }\end{array}$ \\
\hline $\begin{array}{l}\text { Kelompok } \\
\text { Homogen }\end{array}$ & 30 & & & & \\
\cline { 1 - 2 } $\begin{array}{l}\text { Kelompok } \\
\text { Heterogen }\end{array}$ & 30 & 0.05 & 3.281 & 0.075 & Homogen \\
\hline
\end{tabular}


Berdasarkan hasil pengujian normalitas data dan pengujian homogenitas varian, diperoleh hasil, bahwa data koefisien reliabilitas kedua kelompok tidak berdistribusi normal, dan kedua kelompok berasal dari varians yang homogen, artinya asumsi untuk menggunakan model statistic parametrik tidak terpenuhi, sehingga dalam penelitian ini digunakan model statistic non-parametrik.

Pengujian dua sampel independen dalam statistik non-parametrik menggunakan uji-U atau Mann Withney U-Test dengan bantuan program SPSS 18. Uji-U Mann Withney merupakan tes untuk menguji dua kelompok independen dalam model statistic non- parametrik yang bebas dari asumsi. Hipotesis yang diajukan dalam penelitian ini yaitu:

$H_{0}: \eta_{\text {RebHet }} \leq \eta_{\text {RebHom }}$

$H_{1}: \eta_{\text {RebHet }}>\eta_{\text {RebHom }}$

Keterangan:

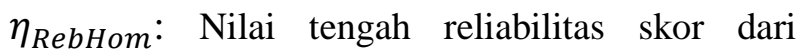
kelompok homogen

$\eta_{\text {RebHet }}$ : Nilai tengah reliabilitas skor dari kelompok heterogen

Kriteria Pengujian:

Jika $H_{0}$ diterima jika $\mathrm{p}$-value $\geq \alpha$

Jika $H_{0}$ ditolak jika p-value $<\alpha$

Hasil dari uji-U Mann Withney dengan bantuan program SPSS 18 diperoleh hasil seperti pada tabel 6 .

\section{Tabel 6. Hasil Uji-U Mann Withney Koefisien Reliabilitas}

Kelompok Homogen dan Kelompok Heterogen

\begin{tabular}{cccccccc}
\hline \multirow{2}{*}{ Aspek } & \multicolumn{2}{c}{$\begin{array}{c}\text { Reliabilitas Skor } \\
\text { Kelompok } \\
\text { Homogen }\end{array}$} & \multicolumn{2}{c}{$\begin{array}{c}\text { Reliabilitas Skor } \\
\text { Kelompok } \\
\text { Homogen }\end{array}$} & $\begin{array}{c}\text { Sig.(2- } \\
\text { tailed) }\end{array}$ & $\begin{array}{c}\text { Taraf } \\
\text { Signifi } \\
\text { kansi }\end{array}$ & Kesimpulan \\
\cline { 2 - 4 } Reliabilitas & 0.56 & 0.073 & 0.79 & 0.038 & 0.000 & 0.05 & $\begin{array}{c}\text { Terdapat perbedaan } \\
\text { yang signifikan }\end{array}$ \\
\hline
\end{tabular}

Hasil pengujian hipotesis memutuskan untuk menolak Hipotesis Nol $\left(H_{0}\right)$ Hal ini menjelaskan bahwa koefisien reliabilitas tes hasil belajar sejarah yang dihasilkan oleh kelompok homogen dan kelompok heterogen berbeda secara signifikan. Hal ini berarti nilainilai koefisien reliabilitas yang muncul bukan merupakan suatu kebetulan.

Hasil pengujian hipotesis sesuai dengan hipotesis yang telah peneliti ajukan sebelumnya, yaitu kelompok heterogen menghasilkan koefisien reliabilitas lebih tinggi dibandingkan dengan kelompok homogen.

Nilai rerata koefisien reliabilitas yang dihasilkan oleh kelompok adalah sebesar 0.56 dengan standar deviasi 0.0073 dengan nilai minimum 0.28 dan nilai maksimum 0.67 sedangkan nilai rerata koefisien reliabilitas yang dihasilkan kelompok heterogen adalah sebesar 0.79 dengan standar deviasi sebesar 0.038 , dengan nilai minimum 0.67 dan nilai maksimum 0.84. Berdasarkan hasil yang diperoleh terlihat bahwa koefisien reliabilitas yang dihasilkan kelompok homogen lebih kecil dibandingkan kelompok heterogen setelah dilakukan penarikan sampel sebanyak 30 kali, meski koefisien reliabilitas dihasilkan kelompok homogen lebih bervariasi, namun nilai terbesar yang dihasilkan hanya sebesar 0.67 , berdasarkan pendapat Wells dan Wollack (2003, dalam Azwar, 2012b: 98) “...untuk tes yang digunakan di kelas oleh para guru hendaknya paling tidak memiliki koefisien reliabilitas 0.70 atau lebih". Maka harga minimal dari koefisien reliabilitas tes yang diharapkan pada penelitian adalah 0.70, sedangkan reliabilitas yang dihasilkan kelompok homogen kurang dari 0.70. dibandingkan 
dengan kelompok heterogen, koefisien reliabilitas tes yang dihasilkan lebih tinggi dengan rata-rata mencapai 0.79 .

Hasil penelitian membuktikan secara empirik teori tentang efek heterogenitas dalam kelompok dapat meningkatkan nilai koefisien reliabilitas yang dihasilkan oleh instrument yang sama. Ini disebabkan oleh varians skor tampak yang dihasilkan. Kelompok homogen menghasilkan varians skor amatan yang lebih kecil yaitu sebesar 14.153 sedangkan varians skor kelompok heterogen yaitu sebesar 18.089. Terdapat beberapa cara dalam melakukan interpretasi terhadap koefisien reliabilitas yaitu dengan mengaitkan reliabilitas dengan varians error dan varians skor tampak seperti yang telah dikemukakan oleh Allen dan Yen (1979, dalam Azwar, 2012: 32)

“... didasari oleh asumsi bahwa varians error diantara populasi yang berbeda adalah tetap sama, maka tinggi atau rendahnya koefisien reliabilitas akan tergantung besar kecilnya varians skor tampak pada populasi yang bersangkutan..."

Karena variansi skor dari kelompok heterogen memiliki nilai lebih besar dibanding kelompok homogen, sehingga nilai varians error atau galat yang terkandung dalam skor amatan dapat diperkecil, dan menaikkan nilai koefisien reliabilitasnya, itulah sebabnya mengapa semakin heterogen suatu kelompok yang dikenai tes, akan menghasilkan koefisien reliabilitas yang tinggi, begitu juga dengan kelompok homogen yang cenderung menghasilkan variansi skor amatan yang cenderung kecil, yang menye-babkan nilai dari varians galat semakin tinggi, sehingga memperkecil koefisien reliabilitas yang dihasilkan meski menggunakan bentuk tes yang sama.

\section{DAFTAR PUSTAKA}

Algina, James dan Crocker, Linda. (1986). Introduction to Classical and Modern Test Theory. Florida: Holt, Rinehart and Winston, Inc.

Ali, Mohammad. (2011). Memahami Riset Prilaku dan Sosial. Bandung: Pustaka Cendekia Utama.

Azwar, Saifuddin. (2011a). Tes Prestasi, Fungsi dan Pengembangan Pengukuran Prestasi Belajar. Jogyakarta: Pustaka Pelajar.

Azwar, Saifuddin. (2011b). Dasar-dasar Psikometri. Jogyakarta: Pustaka Pelajar.

Azwar, Saifuddin. (2012). Reliabilitas dan Validitas, Edisi 4. Yogyakarta: Pustaka Pelajar.

Borg, Walter G, and Gall, Meredith Damien. (1989). Educational Research, An Introduction. Longman: New York

Busnawir, (2006). Pengaruh Moden Penskoran Terhadap Kestabilan Reliabilitas Hasil Pengukuran Skala Sikap Dengan Mempertimbangkan Variasi Usia Responden. Disertasi Doktor pada PPS UNJ Jakarta: Tidak Diterbitkan.

Fraenkel, J.C., Wallen, N.E., Hyun, H.H., (2012). How to Design and Evaluate Research in Education, New York: Mc Graw Hill.

Hasan, S. Hamid. (2012). Pendidikan Sejarah Indonesia: Isu dalam Ide dan Pembelajaran. Bandung: Rizqi Press.

Mardapi, Djemari. (2008). Teknik Penyusunan Instrumen Tes dan Nontes. Yogjakarta: Mitra Cendekia Press.

Nitko, Anthony J and Brookhart, Susan M. (2011). Educational Assessment of Student. Boston: Pearson Education, Inc.

Susetyo, Budi. (2011). Menyusun Tes Hasil Belajar. Bandung: CV Cakra.

Uyanto, Stanislaus. S. (2009). Pedoman Anlisis Data dengan SPSS. Jogyakarta, Graha Ilmu

Zainul, Asmawi. (1993). Penilaian Hasil Belajar. Jakarta: Departemen Pendidikan dan Kebudayaan. 